\title{
The impact of personality on students' perceptions towards online learning
}

\author{
Kaushal Kumar Bhagat \\ Centre for Educational Technology, Indian Institute of Technology, Kharagpur, India
}

\section{Leon Yufeng Wu}

Graduate School of Education \& Center for Teacher Education, Chung-Yuan Christian University, Taiwan

Chun-Yen Chang

Science Education Center, National Taiwan Normal University, Taiwan

\begin{abstract}
The aim of this exploratory study was to examine the impact of five personality traits (extraversion, agreeableness, conscientiousness, neuroticism, and intellect/imagination) on the perception of students towards online learning. A total of 208 students from Taiwan (male $=96$ and female $=112$ ) with previous online course experience participated in an online survey using a bulletin board system. To measure personality traits and students' perceptions, the Mini-International Personality Item Pool and the Perception of Students towards Online Learning instruments were used respectively. The researchers employed hierarchical regression analysis to analyse the data obtained. The results showed that two personality traits (conscientiousness and intellect/imagination) had a larger positive impact on students' perceptions towards online learning, whereas neuroticism had significantly negative effects on participants of online courses. These results provide evidence that students with different personality traits have different preferences for and experiences in online courses.
\end{abstract}

\section{Introduction}

Compared with traditional classroom learning, online learning environments have some features that offer potential advantages, including flexibility, ubiquity, and cost-efficiency (Abrami, Bernard, Bures, Borokhovski, \& Tamim, 2012; Anderson, 2008; Bartley \& Golek, 2004; Fernando, Rosalba, Francisco, Andres, \& Dionicio, 2008; Moller, Robison, \& Huett, 2012; Woods \& Baker, 2004; Zhang, Perris, \& Yeung, 2005). Online courses are flexible, as they do not require physical attendance. Learners can study at their own space. Ubiquity allows students to access course content from almost any place and at any time. Online courses are cost-efficient programs, eliminating commuting and building maintenance costs. In addition, online courses can accommodate more people, be held more frequently, and save infrastructure costs; in these ways, online learning has some advantages over the traditional classroom.

With the recent rapid development in educational technology, online learning has become another way to provide education to learners (Rovai, Ponton, \& Baker, 2008). However, in spite of an increase in the number of online courses, the retention rate of learners in online learning is often below that of learners in traditional full-time courses (Meredith, 2011; Tung, 2012; Zellner, 2011). Atchley, Wingenbach, and Akers (2013) compared the course completion rate between students enrolled in online courses and students enrolled in traditional courses. They found a significant difference in the retention rate between the two groups. In order to engage learners, it is very important to understand individual differences among the learners involved (Bolliger \& Erichsen, 2013; Cela-Ranilla, Gisbert, \& de Oliveira, 2011; ChamorroPremuzic \& Furnham, 2005; O’Connor \& Paunonen, 2007). Bolliger and Erichsen mentioned that personality type affects students' preferences towards educational settings. Some may prefer face-to-face or fully online or even blended learning methods while others prefer fully online courses, and those preferences tend to be correlated with personality types. For example, introverts are likely to prefer asynchronous online courses.

Previous research studies on online learning for degree completion have focused mainly on students' academic performance, motivation, and satisfaction compared with traditional learning environments (Bernard et al., 2004; Caldwell, 2006; Nakayama, Mutsuura, \& Yamamoto, 2014; Schoenfeld-Tacher, McConnell, \& Graham, 2001; Zhan, Xu, \& Ye, 2011). However, the impact of personality traits in online 
learning has not been given ample attention and is in need of further examination. The present study attempts to address this gap by examining the relationship between students' personality traits and their perceptions towards online learning.

\section{Theoretical background}

Funder (1997) defined personality as "an individual's characteristic pattern of thought, emotion, and behavior, together with the psychological mechanisms (hidden or not) behind those patterns" (p. 2). In another definition by McGeown et al. (2014), personality is "a set of underlying traits that determine how an individual typically behaves, thinks and feels" (p. 279). Previous studies have shown that personality is a consistent predictor of student satisfaction (Pawlowska, Westerman, Bergman, \& Huelsman, 2014), university dropout and attrition rates (Alarcon \& Edwards, 2013; Lounsbury, Saudargas, Gibson, \& Leong, 2005), academic motivation (Komarraju \& Karau, 2005; Zhou, 2015), and academic performance (Chamorro-Premuzic \& Furnham, 2003; Pawlowska et al., 2014; Vedel, 2014; Zhou, 2015). From the above studies, we can conclude that personality does play an important role in students' learning experiences. There are many personality trait models available, but a widely accepted and applied model is the fivefactor model (FFM) (Costa \& McCrae, 1992; Randler, Horzum, \& Vollmer, 2014). According to these authors, personality traits can be separated into five factors: extraversion, agreeableness, conscientiousness, neuroticism, and intellect/imagination experience (see Table 1).

Table 1

FFM traits and characteristics

\begin{tabular}{ll}
\hline Personality trait & Characteristics \\
\hline Extraversion & $\begin{array}{l}\text { Ambitious, active, honest, social, interested in people, assertive, and } \\
\text { positive }\end{array}$ \\
Agreeableness & $\begin{array}{l}\text { Flexible, tolerant, amiability, pro-sociality, kind, and cooperative } \\
\text { Organised, efficient, precise, persistent, steady, responsible, systematic, } \\
\text { Conscientiousness }\end{array}$ \\
$\begin{array}{l}\text { and achievement-oriented } \\
\text { Depressed, anxious, irritability, emotional, moodiness and insecure } \\
\text { Intellect/imagination }\end{array}$ & Broad-minded, curious, imaginative and intellect \\
\hline
\end{tabular}

\section{Personality and online learning}

In recent years, there have been some studies that focused on understanding personality traits in online learning. Meredith (2011) studied the relationship between the personality types of students and their success in online courses and found that personality is an influencing factor for the success of students in terms of final course grade and retention rate. Bolliger and Erichsen (2013) investigated the differences in learners' satisfaction in online and blended learning based on their personality type and found that personality type influenced learners' satisfaction in both conditions. In another study, Kelly and Schorger (2002) used the Myers-Briggs Type Indicator and the Student Perceptions of Online Learning to explore the relationship between personality traits and perceptions towards online learning. They concluded that personality traits did influence satisfaction ratings towards online learning, but did not affect achievement of the participants. Keller and Karau (2013) further applied the FFM, developed by Goldberg (1992), and Online Course Impression (OCI) scale, to study the relationship between students' personality and their impressions of online courses. OCI is composed of five dimensions: engagement, value to career, overall evaluation, anxiety/frustration, and preference for online courses. They found conscientiousness as the most consistent predictor for all five dimensions of OCI. Agreeableness and openness predicted only the value to career dimension. However, extraversion and emotional stability showed no significant relationships with any OCI dimensions. Arispe and Blake (2012) used the Big Five Inventory scale to examine the relationship between personality traits and students' preferences in hybrid online language learning and found no significant relationship.

\section{The need for this study}

From the above literature review, three conclusions seem to emerge. First, educators/researchers are still divided on the positive/negative impacts of participants' personality on enrolling in an online course. Second, previous studies (Keller \& Karau, 2013; Kelly \& Schorger, 2002) used long questionnaires, which can make the participants feel bored or irritated and lead them to answer carelessly, resulting in 
measurement error (Donnellan, Oswald, Baird, \& Lucas, 2006). Many empirical studies have shown the advantages of short questionnaires over long questionnaires in terms of effective response rate (Harris, 1997; Salisbury et al., 2005). Third, previous studies (e.g., Keller \& Karau, 2013; Randler et al., 2014; Van Bragt, Bakx, Bergen, \& Croon, 2010) explored the relationship between personality types and perceptions towards online learning; however, most of their survey constructs did not address the design features of online courses. For instance, the studies by Keller and Karau (2013) and Randler et al. (2014) are similar to each other; they focus mainly on acceptance/willingness and anxiety of students towards online learning. These constructs are not helpful in terms of the design perspective (i.e., how to design online courses to minimise problems and accommodate different personality traits).

Previous studies investigated students' acceptance, anxiety, and perceived effectiveness of taking an online course, but those studies did not delineate what the online course would look like or how it would be implemented, deployed and supported. Though some relationships between personality types and perceptions towards online learning (e.g., acceptance, anxiety, and perceived effectiveness of taking an online course) have been found in previous studies, insufficient suggestions have been made to increase students' positive evaluations of online learning to inform a design perspective.

However, in this study, we used the Perception of Students Towards Online Learning (POSTOL) instrument developed and validated by Bhagat, $\mathrm{Wu}$, and Chang (2016), which focuses on design and deployment features of online courses. For example, POSTOL reports on how the instructor should act (instructor characteristics), what forms of the social interactions are desired (social presence), and how the content should be arranged and sequenced (instructional design). In the present study, we tested the following hypotheses:

(1) Extraversion

Learners with extraversion traits involve themselves in human interactions and social activities (Karim, Zamzuri, \& Nor, 2009). In addition, they have strong social needs, which motivate them to complete their course (Komarraju, Karau, \& Schmeck, 2009). Online learning enables participants to communicate and discuss with other participants in a forum. Therefore, we predicted that extraversion will be positively related with positive perceptions towards online learning.

(2) Agreeableness

Agreeable individuals are optimistic and consider people around them to be honest and trustworthy (Karim et al., 2009). They have positive attitude towards new technologies (Zhou \& Lu, 2011). Hence, we predicted that agreeableness will be positively related with positive perception towards online learning.

(3) Conscientiousness

Conscientious students are hardworking, organised and committed (Dollinger, Matyja, \& Huber, 2008; Furnham, Chamorro-Premuzic, \& McDougall, 2003; Van Bragt et al., 2010). They obtain more credits and continue to complete the course (Van Bragt et al., 2010). Keller and Karau (2013) found conscientiousness as a consistent predictor for an individual's perceptions of online learning. Therefore, we predicted that conscientiousness will be positively related with positive perceptions towards online learning.

(4) Neuroticism

Neurotic students suffer from anxiety, self-doubt, and emotionally instability, which can disengage them from learning (Komarraju, Karau, Schmeck, \& Avdic, 2011). They do not actively seek new experiences (Zhou \& Lu, 2011). Based on these stated qualities, we predicted that neuroticism will be negatively related with positive perceptions towards online learning.

(5) Intellect/imagination

Individuals who score high on the trait of intellect are eager to explore new ideas and experiences (Komarraju et al., 2011). They are more willing to attend online courses (Randler et al., 2014). Hence, we predicted that intellect/imagination will be positively related with positive perceptions towards online learning. 


\section{Methodology}

\section{Participants and procedure}

Using a convenience sampling method, a total of 208 students from Taiwan $($ male $=96$ and female $=112$ ) who had online course experience participated in the present study. The mean age was 25.45 years, and students' ages ranged from 18 to 45 years. Out of 208 students, $46.2 \%$ were undergraduates; $45.7 \%$ were master's level students; the remaining $8.2 \%$ were PhD students. Table 2 shows the demographic statistics of the participants. Data collected using a Google online survey form via a bulletin board system.

Table 2

Demographic statistics

\begin{tabular}{llcc}
\hline Measure & Category & Number & Percentage (\%) \\
\hline Gender & Female & 112 & 53.8 \\
& Male & 96 & 46.2 \\
Age (years) & Total & 208 & \\
& $18-25$ & 141 & 67.78 \\
& $26-30$ & 27 & 12.98 \\
& $31-35$ & 19 & 9.13 \\
& 36 and above & 21 & 10.09 \\
Education & Total & 208 & \\
& Undergraduate & 96 & 46.2 \\
& Master & 95 & 45.7 \\
& PhD & 17 & 8.2 \\
\hline
\end{tabular}

\section{Measures}

Mini-International Personality Item Pool (Mini-IPIP)

Students' personality traits were measured using the Mini-IPIP developed by Donnellan et al. (2006). This instrument contains 20 items, with four items belonging to each FFM. We considered this instrument as it contains fewer items than the FFM of Goldberg (1992). This makes it easier for respondents to answer within a limited time without becoming bored and frustrated. Participants responded on a 5-point Likerttype scale ranging from 1 (strongly agree) to 5 (strongly disagree). Donnellan et al. (2006) reported the following Cronbach's alpha coefficients: extraversion .82, agreeableness .75, conscientiousness .75, neuroticism .70, and intellect/imagination .70. Research, by Cooper, Smillie, and Corr (2010), provided evidence for the internal consistency and concurrent validity for the FFM, in the Mini-IPIP. They reported Cronbach's alpha values for the Mini-IPIP are extraversion .81, agreeableness .70, conscientiousness .68, neuroticism .72, and intellect/imagination .70, which is very similar to those reported by Donnellan et al. (2006). Cooper et al. (2010) tested the structural validity of Mini-IPIP using confirmatory factor analysis $(\mathrm{CFA})$. The root mean square error of approximation $(\mathrm{RMSEA})=.07$ and the standardised root mean square residual $(\mathrm{SRMR})=.06$ indices support the acceptability of the model. This result was also supported by Baldasaro, Shanahan, and Bauer (2013). The Cronbach's alpha values for the present study were extraversion .80, agreeableness .79, conscientiousness .78, neuroticism .80, and intellect/imagination .75, which are acceptable.

POSTOL

To measure students' perceptions towards online learning, the POSTOL instrument was employed. It was developed and validated by Bhagat et al. (2016). This instrument consists of four dimensions:

- Instructor characteristics: Lee, Yoon, and Lee (2009) defined instructor characteristics as the extent to which instructors are caring, helpful, and accommodating to students. Lim, Hong, and Tan (2008) mentioned that students were not actively engaged in the e-learning system, unless they were guided and facilitated by instructors who were also active in using the e-learning system. This dimension contains 4 items; for example, "Instructors should provide sufficient learning resources online". 
- Social presence: Tu and McIsaac (2002) defined social presence as "a measure of the feeling of community that a learner experiences in an online environment" (p. 131). Ning Shen and Khalifa (2008) considered social presence as a major design principle in computer-mediated community and an important determinant of online community participation. This dimension contains 4 items; for example, "I think sharing knowledge through online discussions is a good idea".

- Instructional design: Branch (2009) defined instructional design as "an iterative process of planning performance objectives, selecting instructional strategies, choosing media and selecting or creating materials, and evaluation" (p. 8). Identification of instructional principles should be one of the key priorities for the instructional designer in cross-cultural online learning settings (Lim, 2004). This dimension contains 3 items; for example, "Online discussion enables students to exchange ideas and comments".

- Trust: Grandison and Sloman (2000) defined trust as "the firm belief in the competence of an entity to act dependably, securely and reliably within a specified context” (p. 4). Kim and Bonk (2002) emphasised that building and maintaining trust are very important for the success of an online course, resulting in decrease in the dropout rate. This dimension contains 3 items; for example, "I believe that I can earn a better grade in an online course than in a traditional course".

The Cronbach's alpha values for the present study were instructor characteristics .92, social presence .90 , instructional design .72, and trust .73, which is acceptable. CFA results provided satisfactory indices with $\chi^{2}(96)=176.783, \mathrm{p}<.001 ; \mathrm{RMSEA}=.064 ; \mathrm{CFI}=.959 ; \mathrm{GFI}=.914 ; \mathrm{NFI}=.915 ; \mathrm{TLI}=.949$. This indicated that POSTOL was a valid instrument.

\section{Data analysis}

All analyses were performed using the Statistical Package for the Social Sciences, version 21. The statistical significance level was set at $p<0.05$. Hierarchical regression analyses were conducted to examine the effects of groups of independent variables on POSTOL. Standard estimate $(\beta), F$, and adjusted $\mathrm{R}^{2}$ were calculated for each stage.

\section{Results}

The descriptive statistics for independent and dependent variables are provided in Table 3. To examine the normality of the data, skewness and kurtosis were calculated. The skewness and kurtosis values are within the recommended range of $|3|$ and $|10|$ respectively for all the variables (Kline, 2005).

Table 3

Descriptive statistics

\begin{tabular}{lllll}
\hline & Mean & SD & Skewness & Kurtosis \\
\hline Independent variables & & & & \\
Extraversion & 2.84 & .84 & -0.11 & -0.26 \\
Agreeableness & 2.45 & .55 & 0.48 & 1.58 \\
Conscientiousness & 2.46 & .74 & 0.23 & -0.08 \\
Neuroticism & 2.96 & .73 & 0.17 & .24 \\
Intellect/imagination & 2.51 & .78 & 0.01 & -.67 \\
\hline Dependent variables & & & & \\
Instructor characteristics & 1.88 & 0.79 & 1.33 & 2.03 \\
Social presence & 2.11 & 0.73 & 0.94 & 1.316 \\
Instructional design & 2.20 & 0.74 & 0.72 & 0.41 \\
Trust & 2.77 & 0.71 & -0.20 & 0.11 \\
\hline
\end{tabular}

We conducted two-stage hierarchical regression analyses, with each of the four dimensions of POSTOL as the dependent variable. The demographic variables (age, education, and gender) were added in first stage to control the effect of participant's background. The Mini IPIP variables (extraversion, agreeableness, conscientiousness, neuroticism, and intellect/imagination) were added in second stage (see Table 4). 
The hierarchical regression analyses results revealed that at stage 1, demographic variables did not contribute significantly to the regression model for each dependent variables, $F(5,202)=1.819, p=.315$ for instructor characteristics; $F(5,202)=2.369, p=.072$ for social presence; $F(5,202)=2.007, p=.114$ for instructional design; and $F(5,202)=2.188, p=.091$ for trust. In the stage 2 , agreeableness, conscientiousness, neuroticism, and intellect/imagination explained $28.3 \%$ of the variance for instructor characteristics, $F(5,202)=11.219, p<.05$; extraversion, agreeableness, conscientiousness, and intellect/imagination explained $29.1 \%$ of the variance for social presence, $F(5,202)=11.59, p<.05$; agreeableness, conscientiousness, and intellect/imagination explained $21.3 \%$ of the variance for instructional design, $F(5,202)=8.022, p<.05$; and neuroticism, and intellect/imagination explained $6.1 \%$ of the variance for trust, $F(5,202)=2.675, p<.05$.

Table 4

Hierarchical regression analyses results

\begin{tabular}{|c|c|c|c|}
\hline \multirow[t]{2}{*}{ Dependent variable } & \multirow[t]{2}{*}{ Predictor } & \multirow{2}{*}{$\frac{\text { Model 1 }}{\beta}$} & \multirow{2}{*}{$\frac{\text { Model } 2}{\beta}$} \\
\hline & & & \\
\hline & Demographic variables & & \\
\hline & (a) Age & -.028 & -.027 \\
\hline & (b) Education & -.116 & -.008 \\
\hline & (c) Gender & .086 & .017 \\
\hline \multirow[t]{6}{*}{ Instructor characteristics } & Mini IPIP & & \\
\hline & (a) Extraversion & & -.070 \\
\hline & (b) Agreeableness & & $.387^{*}$ \\
\hline & (c) Conscientiousness & & $.304^{*}$ \\
\hline & (d) Neuroticism & & $.165^{*}$ \\
\hline & (e) Intellect/imagination & & $.265^{*}$ \\
\hline Adjusted $\mathrm{R}^{2}$ & & .003 & .283 \\
\hline F change & & 1.189 & 11.219 \\
\hline Sig. F change & & .315 & .000 \\
\hline & Demographic variables & & \\
\hline & (a) Age & .042 & .099 \\
\hline & (b) Education & $-.167^{*}$ & -.057 \\
\hline & (c) Gender & -.03 & -.043 \\
\hline \multirow[t]{6}{*}{ Social presence } & Mini IPIP & & \\
\hline & (a) Extraversion & & $-.166^{*}$ \\
\hline & (b) Agreeableness & & $.351^{*}$ \\
\hline & (c) Conscientiousness & & $.192^{*}$ \\
\hline & (d) Neuroticism & & -.042 \\
\hline & (e) Intellect/imagination & & $.383^{*}$ \\
\hline Adjusted $\mathrm{R}^{2}$ & & .019 & .291 \\
\hline F change & & 2.369 & 11.59 \\
\hline Sig. F change & & .072 & .000 \\
\hline & Demographic variables & & \\
\hline & (a) Age & .005 & -.002 \\
\hline & (b) Education & -.163 & -.063 \\
\hline & (c) Gender & -.021 & -.055 \\
\hline \multirow[t]{6}{*}{ Instructional design } & Mini IPIP & & \\
\hline & (a) Extraversion & & .148 \\
\hline & (b) Agreeableness & & $.176^{*}$ \\
\hline & (c) Conscientiousness & & $.255^{*}$ \\
\hline & (d) Neuroticism & & .095 \\
\hline & (e) Intellect/imagination & & $.253^{*}$ \\
\hline Adjusted $\mathrm{R}^{2}$ & & .014 & .213 \\
\hline F change & & 2.007 & 8.022 \\
\hline Sig. F change & & .114 & .000 \\
\hline
\end{tabular}




\begin{tabular}{llcc}
\hline & Demographic variables & \\
& (a) Age & -.042 & .012 \\
& (b) Education & -.135 & -.096 \\
(c) Gender & -.087 & -.051 \\
Trust & Mini IPIP & & \\
& (a) Extraversion & -.134 \\
& (b) Agreeableness & .056 \\
& (c) Conscientiousness & & .052 \\
& (d) Neuroticism & & $-.175^{*}$ \\
Adjusted R & (e) Intellect/imagination & & $.169^{*}$ \\
F change & & .017 & .061 \\
Sig. F change & & 2.188 & 2.675 \\
\hline * & & .091 & .008 \\
\hline
\end{tabular}

\section{Discussion}

Based on the standardised regression coefficient $(\beta)$ values, it is found that agreeableness $(\beta=.387)$ predicted instructor characteristics more strongly as compared to conscientiousness $(\beta=.304)$, neuroticism $(\beta=.165)$, and intellect/imagination $(\beta=.265)$. This result may be because students with high levels of agreeableness expect positive reinforcement from the instructors to amplify their learning ability. However, intellect/imagination $(\beta=.383)$ predicted social presence more strongly as compared to extraversion $(\beta=$ $-.166)$, agreeableness $(\beta=.351)$, and conscientiousness $(\beta=.192)$. Intellect/imagination as a personality trait is described as curious and broad-minded. This result indicates that students with a higher score on intellect/imagination are more likely to interact with the other participants and instructors to broaden their knowledge (Komarraju et al., 2011). Conscientiousness $(\beta=.255)$ predicted instructional design more strongly as compared to agreeableness $(\beta=.176)$ and intellect/imagination $(\beta=.253)$. Conscientiousness is referred to the individuals who are more organised, persistent, and achievement-oriented (Costa \& McCrae, 1992). Therefore, students with conscientiousness as a personality trait are more oriented towards systematic course structure and content, which will help them to achieve their future learning goals. Regression analyses results showed neuroticism as a predictor. Neuroticism $(\beta=-.175)$ predicted trust more strongly as compared to intellect/imagination $(\beta=.169)$. A possible reason behind this result is that participants with the neuroticism trait are very emotional and find difficulty to familiarise themselves with a social community. This result is in contrast with the finding of Keller and Karau (2013) in which they showed no significant effect of neuroticism with online learning. Neuroticism is a complex trait and deserves further investigation. Moreover, from a design perspective, it is not at all clear what might be done to minimise the negative effects of neuroticism. Students enrolling in online courses should feel free to ask questions and answer other participants' questions. When they do, they become more engaged and interactive in online courses, and, as a result, they are more likely to succeed. Interestingly, it is found that intellect/imagination predicted all the four constructs of POSTOL. This finding suggests that students with a higher score on intellect/imagination are more likely to take online courses.

Online course providers are increasing rapidly across the globe (KPMG \& Google, 2017; Seaman, Allen, \& Seaman, 2015). However, participants' completion rates in online courses are not quite as high as in traditional courses (Zellner, 2011). Thus, it is very important to identify the factors affecting a participant's perception towards online courses.

\section{Recommendations}

Based on our study, we offer two recommendations. First, during enrolment in online courses, learners' personality traits should be identified using standardised personality tests. Online courses should be broad enough to accommodate more students with different personalities. Identifying the personality traits which are associated with students' perceptions will help the instructional designer to customise the teaching/course materials suitable to each participant in an online course. This would result in effective teaching and learning processes and improved academic performance. In addition, understanding the specific demands of students with distinct personality traits would guide instructors in identifying effective teaching methods when teaching online courses. For example, to increase participation of neurotic students, instructors need to give immediate and positive feedback or explain a learner's doubts clearly, which will 
build the participant's trust in the said online course. Second, online courses should incorporate an adaptive learning model, in order to best match courses with a learner's personality. These two would increase the engagement of the participants and motivate them to complete said courses; the results would be increased completion rates of online courses and a decrease in dropout rates, which is a major concern for online course providers (Rostaminezhad, Mozayani, Norozi, \& Iziy, 2013). Further research work is already underway as we are developing online courses based on different personality traits.

\section{Limitations and future directions}

While the present study contributes to the growing body of research on the relationship between student's personality and their perceptions towards online learning, there are some limitations that should be acknowledged. Firstly, this study explored the general relationship between personality and online learning perception. More in-depth research study is needed to identify the specific design elements of online learning influenced by specific personality traits. Secondly, this study did not control for the effect of prior mutual online learning experience. Thirdly, this study employed self-reported questionnaire responses to collect data, which could result in a response bias. It may be that adding interviews and shifting this to include a qualitative component would make the outcomes more meaningful and explain those items that either did or did not have the statistical support we noted was unclear in terms of their value. Improving the value overall of the piece with better information about the relevance of these items in a selection of respondent's own words would give substantially more power to this study. Future research studies should include qualitative data (e.g., interview) to explore the findings obtained from survey results. Further research pertaining to the likely impact of different personality traits on learning and performance in online environments is suggested.

\section{Conclusion}

The present study is one of the few studies that has attempted to explore the relationship between students' personality traits and their perception towards online learning. The results indicated that FFM influenced the participant's perception in online learning. The POSTOL instrument contains dimensions (instructor characteristics, social presence, instructional design and trust) which describe important design features of online learning. Design features of an effective online course include: flexibility, interactivity, supportiveness and motivation. POSTOL describes online courses as a learning environment that provides opportunities for the participants to interact both with the instructor and their peers; it fosters teacherstudent and student-student interaction and creates a social presence which may result in decreased dropout rates (Bhagat et al., 2016). From the results of hierarchical regression analyses, we conclude that students' preferences towards the design features of online courses are significantly related to their personality types. This is the major contribution of our study to the online learning literature compared to previous studies.

\section{References}

Abrami, P., Bernard, R., Bures, E., Borokhovski, E., \& Tamim, R. (2012). Interaction in distance education and online learning: Using evidence and theory to improve practice. In L. Moller \& J. B. Huett (Eds.), The next generation of distance education (pp. 49-69). Boston, MA: Springer US.

Alarcon, G. M., \& Edwards, J. M. (2013). Ability and motivation: Assessing individual factors that contribute to university retention. Journal of Educational Psychology, 105(1), 129-137. https://doi.org/10.1037/a0028496

Anderson, T. (2008). The theory and practice of online learning (2nd ed.). Edmonton: Athabasca University Press.

Arispe, K., \& Blake, R. J. (2012). Individual factors and successful learning in a hybrid course. System, 40(4), 449-465. https://doi.org/10.1016/j.system.2012.10.013

Atchley, T., Wingenbach, G., \& Akers, C. (2013). Comparison of course completion and student performance through online and traditional courses. The International Review of Research in Open and Distance Learning, 14(4), 104-116. https://doi.org/10.19173/irrodl.v14i4.1461

Baldasaro, R. E., Shanahan, M. J., \& Bauer, D. J. (2013). Psychometric properties of the mini-IPIP in a large, nationally representative sample of young adults. Journal of Personality Assessment, 95(1), 74 84. https://doi.org/10.1080/00223891.2012.700466 
Bartley, S. J., \& Golek, J. H. (2004). Evaluating the cost effectiveness of online and face-to-face instruction. Educational Technology \& Society, 7(4), 167-175. Retrieved from https://www.jets.net/ETS/journals/7 4/16.pdf

Bernard, R. M., Abrami, P. C., Lou, Y., Borokhovski, E., Wade, A., Wozney, L., ... Huang, B. (2004). How does distance education compare with classroom instruction? A meta-analysis of the empirical literature. Review of Educational Research, 74(3), 379-439. https://doi.org/10.3102/00346543074003379

Bhagat, K. K., Wu, L. Y., \& Chang, C. Y. (2016). Development and validation of the perception of students towards online learning (POSTOL). Educational Technology \& Society, 19(1), 350-359.

Bolliger, D. U., \& Erichsen, E. A. (2013). Student satisfaction with blended and online courses based on personality type. Canadian Journal of Learning and Technology, 39(1). https://doi.org/10.21432/T2B88W

Branch, R. M. (2009). Instructional design: The ADDIE approach. New York, NY: Springer.

Caldwell, E. R. (2006). A comparative study of three instructional modalities in a computer programming course: Traditional instruction, Web-based instruction, and online instruction (Doctoral dissertation). Retrieved from ProQuest Dissertations \& Theses A\&I database. (Order No. 3227694 )

Cela-Ranilla, J. M., Gisbert, M., \& de Oliveira, J. M. (2011). Exploring the relationship among learning patterns, personality traits, and academic performance in freshmen. Educational Research and Evaluation, 17(3), 175-192. https://doi.org/10.1080/13803611.2011.599564

Chamorro-Premuzic, T., \& Furnham, A. (2003). Personality predicts academic performance: Evidence from two longitudinal university samples. Journal of Research in Personality, 37(4), 319-338. https://doi.org/10.1016/S0092-6566(02)00578-0

Chamorro-Premuzic, T., \& Furnham, A. (2005). Intellectual competence. The Psychologist, 18(6), 352354. Retrieved from https://thepsychologist.bps.org.uk/volume-18/edition-6/intellectual-competence

Cooper, A. J., Smillie, L. D., \& Corr, P. J. (2010). A confirmatory factor analysis of the Mini-IPIP fivefactor model personality scale. Personality and Individual Differences, 48(5), 688-691. https://doi.org/10.1016/j.paid.2010.01.004

Costa, P. T., \& McCrae, R. R. (1992). Revised NEO Personality Inventory (NEO-PI-R) and NEO FiveFactor Inventory (NEO-FFI): professional manual. Odessa, FL: Psychological Assessment Resources.

Dollinger, S. J., Matyja, A. M., \& Huber, J. L. (2008). Which factors best account for academic success: Those which college students can control or those they cannot? Journal of Research in Personality, 42(4), 872-885. https://doi.org/10.1016/j.jrp.2007.11.007

Donnellan, M. B., Oswald, F. L., Baird, B. M., \& Lucas, R. E. (2006). The mini-IPIP scales: Tiny-yeteffective measures of the Big Five factors of personality. Psychological Assessment, 18(2), 192-203. https://doi.org/10.1037/1040-3590.18.2.192

Fernando, Z., Rosalba, C., Francisco, L., Andres, V., \& Dionicio, Z. (2008). u-Teacher: Ubiquitous learning approach. In Z. Pan, X. Zhang, A. El Rhalibi, W. Woo, \& Y. Li (Eds.), Technologies for elearning and digital entertainment (Vol. 5093, pp. 9-20). Nanjing: Springer.

Funder, D. (1997). The personality puzzle. New York, NY: Norton.

Furnham, A., Chamorro-Premuzic, T., \& McDougall, F. (2003). Personality, cognitive ability, and beliefs about intelligence as predictors of academic performance. Learning and Individual Differences, 14(1), 47-64. https://doi.org/10.1016/j.lindif.2003.08.002

Goldberg, L. R. (1992). The development of markers for the Big-Five factor structure. Psychological Assessment, 4, 26-42. https://doi.org/10.1037/1040-3590.4.1.26

Grandison, T., \& Sloman, M. (2000). A survey of trust in internet applications. Communications Surveys \& Tutorials, IEEE, 3(4), 2-16. https://doi.org/10.1109/COMST.2000.5340804

Harris, C. (1997). Developing online market research methods and tools. Retrieved from http://www.harrisresearchpartners.com/lisbon-paper.html

Karim, N. S. A., Zamzuri, N. H. A., \& Nor, Y. M. (2009). Exploring the relationship between Internet ethics in university students and the big five model of personality. Computers \& Education, 53(1), 86-93. https://doi.org/10.1016/j.compedu.2009.01.001

Keller, H., \& Karau, S. J. (2013). The importance of personality in students' perceptions of the online learning experience. Computers in Human Behavior, 29(6), 2494-2500. https://doi.org/10.1016/j.chb.2013.06.007

Kelly, K. L., \& Schorger, J. (2002). Online learning: Personalities, preferences and perceptions. Retrieved from ERIC database. (ED470663) 
Kim, K. J., \& Bonk, C. J. (2002). Cross-cultural comparisons of online collaboration. Journal of Computer-Mediated Communication, 8(1). https://doi.org/10.1111/j.1083-6101.2002.tb00163.x

Kline, R. B. (2005). Principles and practice of structural equation modeling (2nd ed.). New York, NY: Guilford Press.

Komarraju, M., \& Karau, S. J. (2005). The relationship between the big five personality traits and academic motivation. Personality and Individual Differences, 39(3), 557-567. https://doi.org/10.1016/i.paid.2005.02.013

Komarraju, M., Karau, S. J., \& Schmeck, R. R. (2009). Role of the Big Five personality traits in predicting college students' academic motivation and achievement. Learning and Individual Differences, 19(1), 47-52. https://doi.org/10.1016/j.lindif.2008.07.001

Komarraju, M., Karau, S. J., Schmeck, R. R., \& Avdic, A. (2011). The Big Five personality traits, learning styles, and academic achievement. Personality and Individual Differences, 51(4), 472-477. https://doi.org/10.1016/j.paid.2011.04.019

KPMG, \& Google. (2017). Online education in India: 2021. Retrieved from https://assets.kpmg.com/content/dam/kpmg/in/pdf/2017/05/Online-Education-in-India-2021.pdf

Lee, B. C., Yoon, J. O., \& Lee, I. (2009). Learners' acceptance of e-learning in South Korea: Theories and results. Computers \& Education, 53(4), 1320-1329. https://doi.org/10.1016/j.compedu.2009.06.014

Lim, B., Hong, K. S., \& Tan, K. W. (2008). Acceptance of e-learning among distance learners: A Malaysian perspective. In Hello! Where are you in the landscape of educational technology? Proceedings ascilite Melbourne 2008 (pp. 541-551). Retrieved from http://www.ascilite.org/conferences/melbourne08/procs/lim.pdf

Lim, D. H. (2004). Cross cultural differences in online learning motivation. Educational Media International, 41(2), 163-173. https://doi.org/10.1080/09523980410001685784

Lounsbury, J., Saudargas, R., Gibson, L., \& Leong, F. (2005). An investigation of broad and narrow personality traits in relation to general and domain-specific life satisfaction of college students. Research in Higher Education, 46(6), 707-729. https://doi.org/10.1007/s11162-004-4140-6

McGeown, S. P., Putwain, D., Geijer Simpson, E., Boffey, E., Markham, J., \& Vince, A. (2014). Predictors of adolescents' academic motivation: Personality, self-efficacy and adolescents' characteristics. Learning and Individual Differences, 32, 278-286. https://doi.org/10.1016/j.lindif.2014.03.022

Meredith, B. P. (2011). Personality types as an indicator of online student success and retention (Doctoral dissertation). Retrieved from ProQuest Dissertations \& Theses Global. (Order No. 3449391)

Moller, L., Robison, D., \& Huett, J. (2012). Unconstrained learning: Principles for the next generation of distance education. In L. Moller \& J. B. Huett (Eds.), The next generation of distance education (pp. 1-19). Boston, MA: Springer.

Nakayama, M., Mutsuura, K., \& Yamamoto, H. (2014). Impact of learner's characteristics and learning behaviour on learning performance during a fully online course. The Electronic Journal of eLearning, 12(4), 396-410. Retrieved from http://www.ejel.org/issue/download.html?idArticle=308

Ning Shen, K., \& Khalifa, M. (2008). Exploring multidimensional conceptualization of social presence in the context of online communities. International Journal of Human-Computer Interaction, 24(7), 722-748. https://doi.org/10.1080/10447310802335789

O’Connor, M. C., \& Paunonen, S. V. (2007). Big Five personality predictors of post-secondary academic performance. Personality and Individual Differences, 43(5), 971-990. https://doi.org/10.1016/j.paid.2007.03.017

Pawlowska, D. K., Westerman, J. W., Bergman, S. M., \& Huelsman, T. J. (2014). Student personality, classroom environment, and student outcomes: A person-environment fit analysis. Learning and Individual Differences, 36, 180-193. https://doi.org/10.1016/j.lindif.2014.10.005

Randler, C., Horzum, M. B., \& Vollmer, C. (2014). The influence of personality and chronotype on distance learning willingness and anxiety among vocational high school students in Turkey. The International Review of Research in Open and Distributed Learning, 15(6). Retrieved from http://www.irrodl.org/index.php/irrodl/article/view/1928

Rostaminezhad, M. A., Mozayani, N., Norozi, D., \& Iziy, M. (2013). Factors related to e-learner dropout: case study of IUST Elearning Center. Procedia - Social and Behavioral Sciences, 83, 522-527. https://doi.org/10.1016/j.sbspro.2013.06.100

Rovai, A. P., Ponton, M. K., \& Baker, J. D. (2008). Distance learning in higher education: A programmatic approach to planning, design, instruction, evaluation, and accreditation. New York, NY: Teachers College Press. 
Salisbury, C., Burgess, A., Lattimer, V., Heaney, D., Walker, J., Turnbull, J., \& Smith, H. (2005). Developing a standard short questionnaire for the assessment of patient satisfaction with out-of-hours primary care. Family Practice, 22(5), 560-569. https://doi.org/ 10.1093/fampra/cmi050

Schoenfeld-Tacher, R., McConnell, S., \& Graham, M. (2001). Do no harm: A comparison of the effects of on-line vs. traditional delivery media on a science course. Journal of Science Education and Technology, 10(3), 257-265. https://doi.org/10.1023/A:1016690600795

Seaman, J. E., Allen, E., \& Seaman, J. (2015). Online report card: Tracking online education in the United States. Newbury Port, MA: Babson Survey Research Group. Retrieved from https://onlinelearningconsortium.org/read/online-report-card-tracking-online-education-united-states$2015 /$

Tu, C.-H., \& McIsaac, M. (2002). The relationship of social presence and interaction in online classes. American Journal of Distance Education, 16(3), 131-150. https://doi.org/10.1207/S15389286AJDE1603 2

Tung, L. C. (2012). Proactive intervention strategies for improving online student retention in a Malaysian distance education institution. Journal of Online Learning and Teaching, 8(4), 312-323. Retrieved from http://jolt.merlot.org/vol8no4/tung_1212.pdf

Van Bragt, C. A. C., Bakx, A. W. E. A., Bergen, T. C. M., \& Croon, M. A. (2010). Looking for students' personal characteristics predicting study outcome. Higher Education, 61(1), 59-75. https://doi.org/10.1007/s10734-010-9325-7

Vedel, A. (2014). The Big Five and tertiary academic performance: A systematic review and metaanalysis. Personality and Individual Differences, 71, 66-76. https://doi.org/10.1016/j.paid.2014.07.011

Woods, R. H., \& Baker, J. D. (2004). Interaction and immediacy in online learning. The International Review of Research in Open and Distributed Learning, 5(2). Retrieved from http://www.irrodl.org/index.php/irrodl/article/view/186/268

Zellner, K. S. (2011). Measuring and improving online student retention. Washington, DC: The Advisory Board Company. Retrieved from http://www.uky.edu/ie/sites/www.uky.edu.ie/files/uploads/EAB RM Measuring-and-ImprovingOnline-Student-Retention.pdf

Zhan, Z., Xu, F., \& Ye, H. (2011). Effects of an online learning community on active and reflective learners' learning performance and attitudes in a face-to-face undergraduate course. Computers \& Education, 56(4), 961-968. https://doi.org/10.1016/j.compedu.2010.11.012

Zhang, W. y., Perris, K., \& Yeung, L. (2005). Online tutorial support in open and distance learning: Students' perceptions. British Journal of Educational Technology, 36(5), 789-804. https://doi.org/10.1111/j.1467-8535.2004.00492.x

Zhou, M. (2015). Moderating effect of self-determination in the relationship between Big Five personality and academic performance. Personality and Individual Differences, 86, 385-389. https://doi.org/10.1016/j.paid.2015.07.005

Zhou, T., \& Lu, Y. (2011). The effects of personality traits on user acceptance of mobile commerce. International Journal of Human-Computer Interaction, 27(6), 545-561. https://doi.org/10.1080/10447318.2011.555298

Corresponding author: Chun-Yen Chang, changcy@ntnu.edu.tw

Australasian Journal of Educational Technology (C) 2019.

Please cite as: Bhagat, K. K., Wu, L. Y., \& Chang, C. Y. (2019). The impact of personality on students' perceptions towards online learning. Australasian Journal of Educational Technology, 35(4), 98-108. https://doi.org/10.14742/ajet.4162 